\title{
Employee Performance Assessment using Analytical Network Process and Rating Scale
}

\author{
Riska Septifani *, Panji Deoranto, Tiyas Widya Armanda \\ Teknologi Industri Pertanian, Fakultas Teknologi Pertanian, Universitas Brawijaya Malang, Indonesia \\ Jl. Veteran, Ketawanggede, Malang, East Java 65145, Indonesia \\ * Corresponding author: riskaseptifani@ub.ac.id
}

\section{ARTICLE INFO}

Article history

Received June 27, 2019

Revised February 21, 2020

Accepted February 26, 2020

Available Online February 28, 2020

Keywords

Employee performance

Performance assessment

ANP

Rating scale

\begin{abstract}
Employee performance assessment is an essential aspect of a company. This study aims to assess employee performance based on Analytical Network Process (ANP) and rating scale. ANP was employed to determine the importance of the criteria. Meanwhile, the rating scale was used to analyze the results of the employee performance assessment. The results of the study showed the weights of the criteria. The highest to lowest weights in sequence included the skills to carry out tasks, job performance, ability to cooperate, employment relationship, and personality. Based on the assessment of fifty-three employees of HRD and Corporate Secretary and General Counsel Department, one employee showed outstanding performance, four employees exemplified high performance, forty-five employees met the standard performance, and three employees had low performance.
\end{abstract}

This is an open-access article under the CC-BY-SA license.

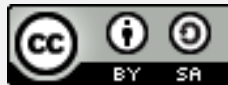

\section{Introduction}

Employees play an essential role in the success and competitiveness of a company [1]. In an organization, each employee has different areas of expertise and skills [2]. Performance assessment is a process needed to organize human resources. It also has an impact on the development of the organization [3]. The key to the success of the organization is influenced by employee performance [4]. Although the organization is highly dependent on technology, employees remain an essential factor for their success [5]. Performance assessment is imperative to be done in the Human Resource Department (HRD) and the company's management section [6]. Performance assessment is used to measure the company's achievement in completing the specified targets [7]. It is also to measure the efficiency and effectiveness of the employees [8]. Performance assessment provides information to improve the performance of the employees [9]. The assessment results can be used for promotions, salary increments, and rewards and training for the employees [10]. Performance assessment is the responsibility of the manager to evaluate the performance of the employees [11]. The manager's capability to make the appropriate evaluation can support the company to maintain and achieve its vision and mission [12]. Therefore, assessors need high evaluation standards [13] and appropriate methods [14]. Appropriate assessment methods may help the manager provide ratings to their employees [15]. 
In general, employees' performance assessment uses an average score. Also, the criteria used do not have any weight. As a result, the most important criteria for evaluating employee performance are usually unknown. Employee performance assessment has to be adjusted to the needs of the company [16]. The appropriate measurement methods are needed so that performance evaluation can be carried out effectively [14]. Several studies on performance assessment have been conducted out in various fields. The popular method used by many researchers is the Analytical Hierarchy Process (AHP) and the Analytic Network Process (ANP). Ilhami and Rimantho [17] proposed the AHP method and rating scale in evaluating employee performance. Arin, et al. [18] made use of the ANP method to assess supplier performance. Sestri [19] employed the AHP method to evaluate lecturer performance. Saefudin et al. [20] also used AHP for the assessment of employee performance assessment. Subiyanto et al. [21] developed an intelligence technique for soybean assessment. Campeol et al. [22] used AHP to assess infrastructure.

According to the previous studies, one of the popular methods used to assess performance is Analytical Network Process (ANP). However, little attention is paid to the problem of employee performance assessment. This study aims to assess employee performance using the ANP method and rating scale. ANP has many advantages. ANP can be employed to determine the weight of the criteria and sub-criteria in performance assessment [23]. ANP can explain the interrelationship between criteria and sub-criteria [24]. Therefore, the selection of decisions can be made appropriately and objectively [25]. Besides, ANP uses pairwise comparison [26] so that the comparison can be made reasonably. In this study, ANP is used to determine the weight of the criteria and subcriteria.

Furthermore, the weight of criteria is used to assess the employee performance using the rating scale. This study provides essential insights in evaluating employee performance using the ANP method and rating scale. The organization of this paper includes the introduction in section 1, determination of criteria and sub-criteria, proposed method (ANP and rating scale), and data collection in section 2 . Section 3 describes the results of the criteria and sub-criteria weight and employee performance assessment. Finally, the last part of this paper presents the conclusion and suggestions for further research.

\section{Methods}

This section presents the criteria and sub-criteria, proposed methods (integration of ANP and rating scale), and data collection procedures to evaluate employee performance. These three subsections are explained as follows.

\subsection{Criteria and sub-criteria}

We used five criteria and fifteen sub-criteria to assess employee performance. Details of the criteria and sub-criteria can be seen in Table 1. The criteria for evaluating the employee performance used included job performance (JP) [17], skills to carry out tasks (SCT) [27], ability to cooperate (AC) [17], personality (P) [27], and employment relationship (ER) [27]. These criteria are based on a review of previous research studies.

\subsection{Proposed Methods}

This study proposed the integration of ANP and rating scale to evaluate employee performance. In this study, ANP was employed to determine the criteria weight and sub- 
criteria assessment of employee performance. Furthermore, the results of the criteria weight were used to assess employee performance using the rating scale. The framework of the proposed ANP integration method and rating scale is presented in Fig. 1. We identified the criteria and sub-criteria in assessing the employee performance shown in the previous sub-chapter. The network (interdependence) model of the employee performance assessment can be seen in Fig. 2. This study employed the ANP method proposed by Saaty [30]. The ANP measurement scale used a scale of 1 to 9. The scale is described as follows; 1 shows equal importance, 3 shows moderate importance, 5 shows essential importance, 7 shows high importance, and 9 shows extreme importance.

Table 1. Criteria and sub-criteria of job performance in PT X

No Criteria

1. Job performance (JP) [19]

2. Skills to carry out tasks (SCT) [27]
Sub criteria

Ability to complete tasks (JP1) [27]

Accepting responsibility (JP2) [17]

Task completion speed (JP3) [27]

Creativity (SCT1) [28]

Initiative (SCT2) [28]

Ability to coordinate different types of work (quantity) (SCT3) [29]

3. Ability to cooperate (AC) [17]

Good team management (AC1) [17]

Maintaining a good relationship with the team (AC2) [17]

4. Personality $(\mathrm{P})[27]$

Honesty (P1) [29]

Spirit of work (P2) [27]

Discipline (P3) [17]

Attendance (P4) [19]

5. Employment relationship

(ER) [27]
Attitude toward superiors (ER1) [27]

Attitude toward colleagues (ER2) [27]

Attitude toward subordinates (ER3) [27]

The stage of weighting the criteria and sub-criteria was carried out using Super decision software. Each employee was rated on the rating scale for each criterion that used the rating scale 1-5. This scale is described in Table 2. Furthermore, the results of the rating scale and weighting on ANP were used to assess employee performance. The final score of the employee performance assessment was done by multiplying the criteria weight, subcritical weight, and rating scale score. This study proposed five categories of employee performance, as shown in Table 3 [31].

Table 2. Scale of employee performance assessment

\begin{tabular}{cl} 
Assessment scale & \multicolumn{1}{c}{ Explanation } \\
1 & Unsatisfactory Performance \\
2 & Improvement Desired \\
3 & Meets Expectation \\
4 & Exceeds Expectation \\
5 & Outstanding Performance
\end{tabular}




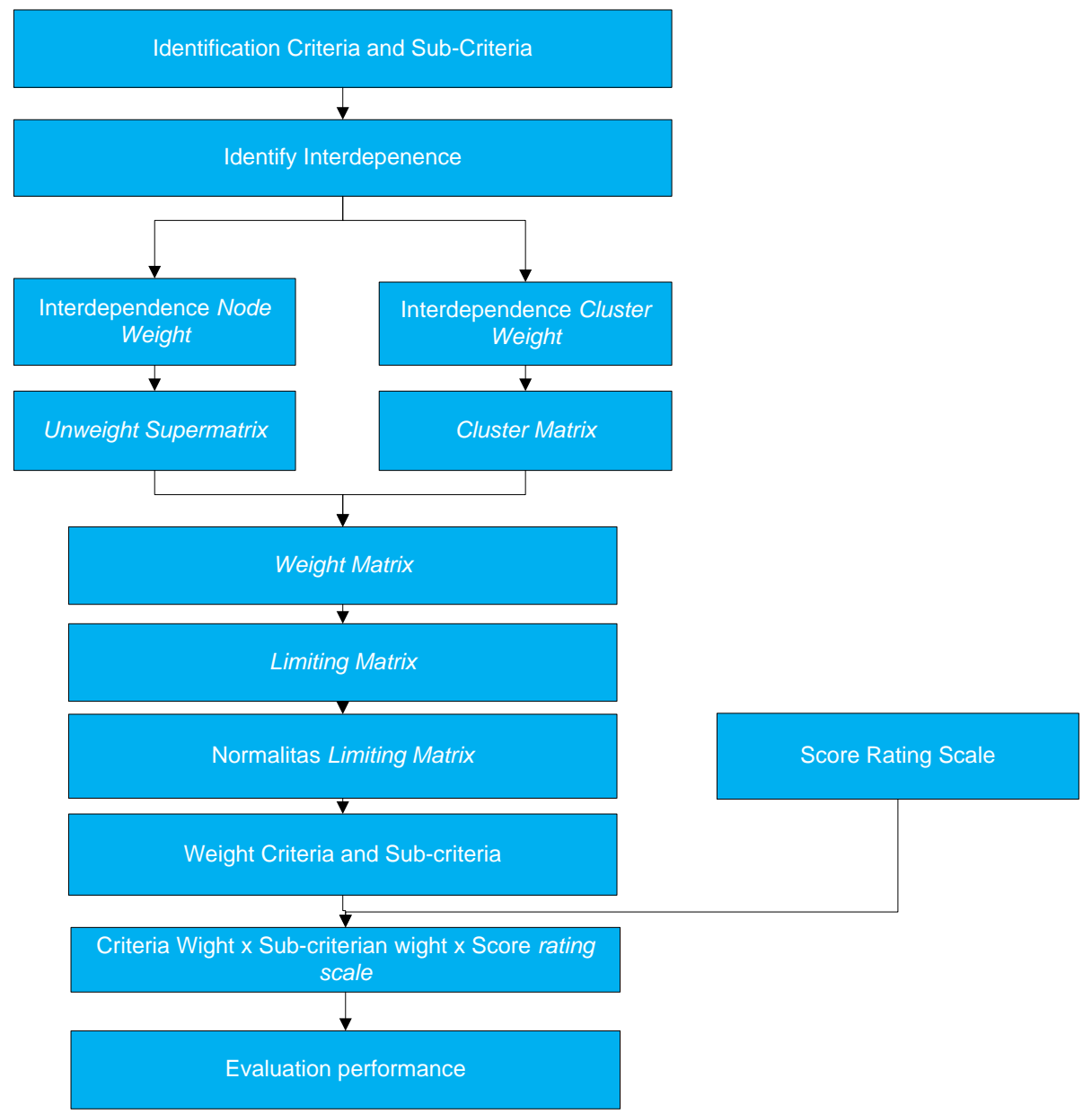

Fig. 1. The framework of employee performance with ANP and rating scale

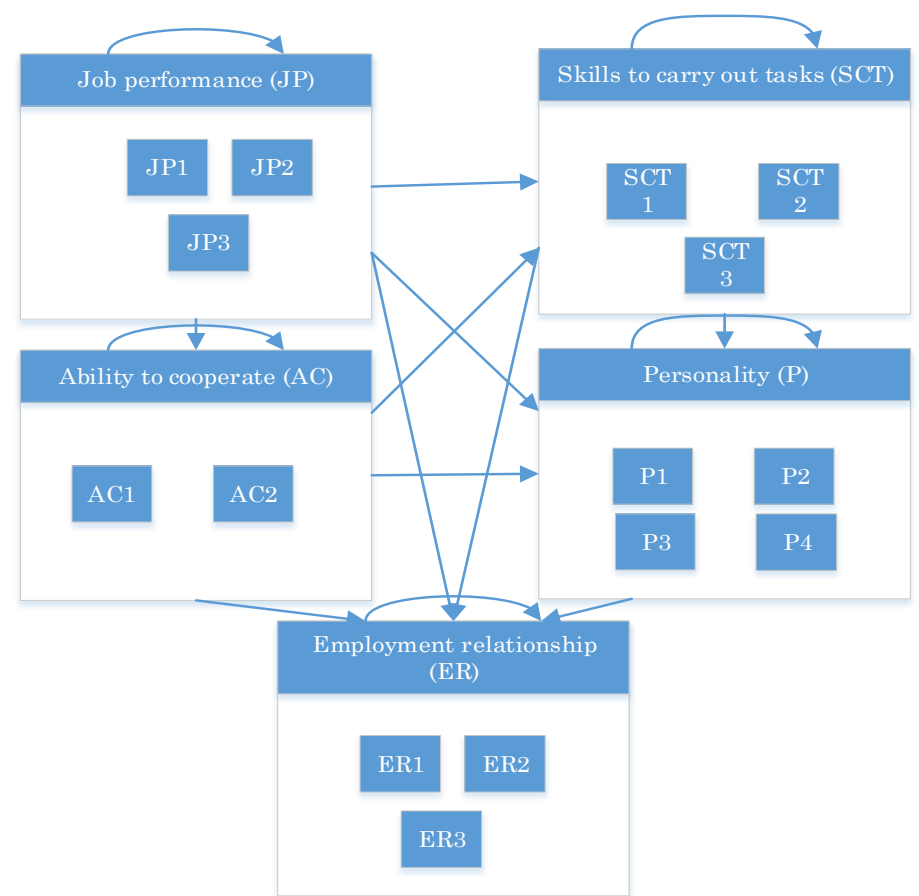

Fig. 2. Model of the network (interdependence) of employee performance assessment 
Table 3. Category of employee performance assessment

\begin{tabular}{lccc} 
No & Value Scale & Category & Value Interval \\
1. & A & Outstanding performance & $4.20<\mathrm{n}<5.00$ \\
2. & B & Exceed expectation & $3.40<\mathrm{n}<4.20$ \\
3. & C & Meets expectation & $2.60<\mathrm{n}<3.40$ \\
4. & D & Improvement desired & $1.80<\mathrm{n}<2.60$ \\
5. & E & Unsatisfactory performance & $1<\mathrm{n}<1.80$ \\
\hline
\end{tabular}

\subsection{Data Collection}

This study was carried out in palm oil, rubber, tea, and coffee companies in Indonesia. The data collection process was done by filling out the questionnaire by respondents. Two surveys were used for weighting the criteria, sub-criteria, and rating scale assessment. The respondent of this study was one head of the Human Resources Department (HRD) and one head of the employee sub-department. The respondents surveyed the criteria weight. Respondents also had a Focus Group Discussion (FGD) to determine the importance of both criteria and sub-criteria.

Furthermore, the head of the HRD and the head of the employee sub-department assessed eleven employees in the HRD. Respondents assessed eleven employees in the HRD and forty-two employees of the Corporate Secretary and General Counsel Department. The employee performance was assessed in one year (2018).

\section{Results and Discussion \\ 3.1 Criteria weight with Analytical Network Process (ANP)}

The weight of the criteria and sub-criteria using the ANP method can be seen in Table 4. The results indicate that there was a link among several criteria. The sub-criteria of accepting responsibility affected the ability to complete tasks. Furthermore, the ability to complete tasks affected the ability to coordinate different types of work.

The skills to carry out tasks ranked the first of the five criteria. It yielded a weight of 0.372 . The highest sub-criterion weight value in the criteria of skills to carry out tasks was initiative (SCT2). The lowest sub-criterion value in this criterion was creativity (SCT2). These results contradicted the study conducted by Lakoy [32]. However, creativity is still needed to improve employee performance [32]. Job performance criteria weighted 0.359. This criterion was considered necessary for the respondents after the skills to carry out tasks. The highest weight of this sub-criterion was accepting responsibility (JP2). The lowest weight was the ability to complete tasks (JP3). However, this criterion is also deemed necessary as it can determine the level of employee contribution.

The ability to work together was ranked number three of all criteria. The weight of this criterion was 0.131 . The highest sub-criterion weight in this criterion was good team management (AC1). This result is by Samsuni [33]. Employees who can work synergistically can accelerate the achievement of the organization. Good teamwork is effective in getting the job done quickly [34]. The employment relationship was ranked the fourth of all criteria with a weight value of 0.105 . Attitude toward subordinates had the highest weight. Meanwhile, attitude toward superiors was considered not very important, although it could not be ignored entirely. This result is by Ali, et al [35]. A positive atmosphere in the work environment is essential for improving employee performance [35]. A positive atmosphere in the work environment is vital for improving performance [35]. Personality was ranked the last of all criteria with a weight value of 0.033 . Discipline was the highest sub-criteria. Meanwhile, honesty had the lowest weight. Discipline is one 
of the factors that can affect the achievement of company goals. Furthermore, honesty is considered as an attitude that must be possessed by all employees [36].

Table 4. Hasil Bobot Kriteria dan sub kriteria Kinerja Karyawan

\begin{tabular}{|c|c|c|c|c|}
\hline No & Criteria & Weight & Sub Criteria & Weight \\
\hline \multirow[t]{3}{*}{1.} & \multirow[t]{3}{*}{ Job performance (JP) } & \multirow[t]{3}{*}{0.359} & $\begin{array}{l}\text { Ability to complete tasks } \\
\text { (JP1) }\end{array}$ & 0.083 \\
\hline & & & $\begin{array}{l}\text { Accepting responsibility } \\
\text { (JP2) }\end{array}$ & 0.146 \\
\hline & & & $\begin{array}{l}\text { Task completion speed } \\
\text { (JP3) }\end{array}$ & 0.130 \\
\hline \multirow[t]{3}{*}{2.} & \multirow{3}{*}{$\begin{array}{l}\text { Skills to carry out } \\
\text { tasks (SCT) }\end{array}$} & \multirow[t]{3}{*}{0.372} & Creativity (SCT1) & 0.099 \\
\hline & & & Initiative (SCT2) & 0.145 \\
\hline & & & $\begin{array}{l}\text { Ability to coordinate } \\
\text { different types of work } \\
\text { (quantity) (SCT3) }\end{array}$ & 0.128 \\
\hline \multirow[t]{2}{*}{3.} & \multirow[t]{2}{*}{$\begin{array}{l}\text { Ability to cooperate } \\
\text { (AC) }\end{array}$} & \multirow[t]{2}{*}{0.131} & $\begin{array}{l}\text { Good team management } \\
\text { (AC1) }\end{array}$ & 0.076 \\
\hline & & & $\begin{array}{l}\text { Maintaining a good } \\
\text { relationship with the } \\
\text { team (AC2) }\end{array}$ & 0.055 \\
\hline \multirow[t]{4}{*}{4.} & \multirow[t]{4}{*}{ Personality $(\mathrm{P})$} & \multirow[t]{4}{*}{0.033} & Honesty (P1) & 0.006 \\
\hline & & & Spirit of work (P2) & 0.009 \\
\hline & & & Discipline (P3) & 0.011 \\
\hline & & & Attendance (P4) & 0.007 \\
\hline \multirow[t]{3}{*}{5.} & \multirow[t]{3}{*}{$\begin{array}{l}\text { Employment } \\
\text { relationship (ER) }\end{array}$} & \multirow[t]{3}{*}{0.105} & $\begin{array}{l}\text { Attitude toward } \\
\text { superiors (ER1) }\end{array}$ & 0.022 \\
\hline & & & $\begin{array}{l}\text { Attitude toward } \\
\text { colleagues (ER2) }\end{array}$ & 0.034 \\
\hline & & & $\begin{array}{l}\text { Attitude toward } \\
\text { subordinates (ER3) }\end{array}$ & 0.049 \\
\hline
\end{tabular}

\subsection{Employee Performance Assessment}

The result of the employee performance assessment of HRD can be seen in Table 5. Meanwhile, the result of the employee performance assessment of the Corporate Secretary and General Counsel Department can be seen in Table 6. Based on Table 5, only one employee showed exceptional performance; four other employees exemplified high performance. Six employees performed according to the standards. No employee exemplified poor performance. One factor that can affect employee performance is age. At the age of more than forty years old, work productivity begins to decrease by up to $60 \%$ $80 \%$ as compared to the productive age [37].

Based on the result shown in Table 6, there were thirty-nine employees whose performance met the standards. Meanwhile, three other employees showed low performance. Work experience of fewer than two years has a significant influence on employee performance. This result is in line with Taurisa and Ratnawati [38]. Employees with longer tenure tend to have better job mastery [38]. Therefore, it will improve employee performance. Based on the study results, the ANP method and rating scale are 
effective and relatively easy to use in assessing employee performance. Besides, the employee performance assessment with this method is proven to be more comprehensive.

Table 5. Employee Performance Assessment of HRD Employees

\begin{tabular}{|c|c|c|c|c|c|c|c|}
\hline Ranking & $\begin{array}{l}\text { ID. } \\
\text { Name }\end{array}$ & Grade & Category & Ranking & $\begin{array}{l}\text { ID. } \\
\text { Name }\end{array}$ & Grade & Category \\
\hline 1 & $\mathrm{ST}$ & 4.29 & $\begin{array}{l}\text { Outstanding } \\
\text { performance }\end{array}$ & 7 & IK & 3.20 & Meets expectation \\
\hline 2 & NR & 3.62 & $\begin{array}{c}\text { Exceed } \\
\text { expectation }\end{array}$ & 8 & SD & 3.17 & Meets expectation \\
\hline 3 & $\mathrm{EE}$ & 3.57 & $\begin{array}{c}\text { Exceed } \\
\text { expectation }\end{array}$ & 9 & WS & 2.86 & Meets expectation \\
\hline 4 & SA & 3.56 & $\begin{array}{c}\text { Exceed } \\
\text { expectation }\end{array}$ & 10 & $\mathrm{AM}$ & 2.83 & Meets expectation \\
\hline 5 & $\mathrm{SU}$ & 3.52 & $\begin{array}{l}\text { Exceed } \\
\text { expectation }\end{array}$ & 11 & $\mathrm{FH}$ & 2.83 & Meets expectation \\
\hline 6 & IF & 3.26 & Meets expectation & & & & \\
\hline
\end{tabular}

Table 6. Employee Performance Assessment of the Secretary Corporate and General Counsel Department

\begin{tabular}{|c|c|c|c|c|c|c|c|}
\hline Ranking & $\begin{array}{l}\text { ID. } \\
\text { Name }\end{array}$ & Grade & Category & Ranking & $\begin{array}{l}\text { ID. } \\
\text { Name }\end{array}$ & Grade & Category \\
\hline 1 & FZ & 3.12 & Meets expectation & 22 & MI & 2.88 & Meets expectation \\
\hline 2 & MB & 3.09 & Meets expectation & 23 & $\mathrm{AO}$ & 2.87 & Meets expectation \\
\hline 3 & BY & 3.07 & Meets expectation & 24 & $\mathrm{SN}$ & 2.87 & Meets expectation \\
\hline 4 & JR & 3.04 & Meets expectation & 25 & $\mathrm{AF}$ & 2.87 & Meets expectation \\
\hline 5 & $\mathrm{JO}$ & 3.03 & Meets expectation & 26 & MT & 2.86 & Meets expectation \\
\hline 6 & AK & 3.01 & Meets expectation & 27 & SY & 2.85 & Meets expectation \\
\hline 7 & GP & 3.01 & Meets expectation & 28 & EW & 2.85 & Meets expectation \\
\hline 8 & $\mathrm{MJ}$ & 3.00 & Meets expectation & 29 & HW & 2.80 & Meets expectation \\
\hline 9 & MD & 3.00 & Meets expectation & 30 & $\mathrm{EV}$ & 2.80 & Meets expectation \\
\hline 10 & SR & 2.99 & Meets expectation & 31 & DM & 2.78 & Meets expectation \\
\hline 11 & $\mathrm{SE}$ & 2.99 & Meets expectation & 32 & SI & 2.78 & Meets expectation \\
\hline 12 & $\mathrm{DN}$ & 2.99 & Meets expectation & 33 & $\mathrm{MH}$ & 2.74 & Meets expectation \\
\hline 13 & MU & 2.97 & Meets expectation & 34 & MM & 2.72 & Meets expectation \\
\hline 14 & $\mathrm{SO}$ & 2.96 & Meets expectation & 35 & HL & 2.68 & Meets expectation \\
\hline 15 & $\mathrm{HE}$ & 2.94 & Meets expectation & 36 & LM & 2.68 & Meets expectation \\
\hline 16 & $\mathrm{ZA}$ & 2.93 & Meets expectation & 37 & HS & 2.67 & Meets expectation \\
\hline 17 & AA & 2.92 & Meets expectation & 38 & HK & 2.62 & Meets expectation \\
\hline 18 & KA & 2.91 & Meets expectation & 39 & SL & 2.61 & Meets expectation \\
\hline 19 & RL & 2.90 & Meets expectation & 40 & AS & 2.59 & Improvement desired \\
\hline 20 & IA & 2.89 & Meets expectation & 41 & NG & 2.59 & Improvement desired \\
\hline 21 & WM & 2.88 & Meets expectation & 42 & NR & 2.53 & Improvement desired \\
\hline
\end{tabular}

\section{Conclusion}

The purpose of this study is to assess employee performance using the ANP method and rating scale. ANP was used to determine the weight of the criteria and sub-criteria. Then, the results of the criteria weight were used to assess employee performance with the assistance of the rating scale. This case study assessed fifty-three employees of the HRD and Corporate Secretary and General Counsel Department. The result from HRD indicated that one employee showed outstanding performance, four employees had high performance, and six others performed according to the standard. Meanwhile, the result 
from the Corporate Secretary and General Counsel department showed that thirty-nine employees met the standard of performance, and three employees showed poor performance. In general, the ANP method and rating scale are effective. Besides, it is relatively easy to use in assessing employee performance. For further research, more criteria and sub-criteria can be added, and more expert respondents can improve the comprehensiveness of the study.

\section{References}

[1] J. A. Gruman and A. M. Saks, "Performance management and employee engagement," Human Resource Management Review, vol. 21, pp. 123-136, 2011. https://doi.org/10.1016/j.hrmr.2010.09.004.

[2] H. Melander Bowden and E. Sandlund, "Knowledge talk in performance appraisal interviews," Learning, Culture and Social Interaction, vol. 21, pp. 278-292, 2019. https://doi.org/10.1016/j.lcsi.2019.03.012.

[3] S. Apak, S. Gümüş, G. Öner, and H. G. Gümüş, "Performance Appraisal and a Field Study," Procedia - Social and Behavioral Sciences, vol. 229, pp. 104-114, 2016. https://doi.org/10.1016/j.sbspro.2016.07.119.

[4] M. Alefari, A. M. Fernández Barahona, and K. Salonitis, "Modelling manufacturing employees' performance based on a system dynamics approach," Procedia CIRP, vol. 72, pp. 438-443, 2018. https://doi.org/10.1016/j.procir.2018.03.161.

[5] C. Zehir, H. Yıldız, M. Köle, and D. Başar, "Superior Organizational Performance through SHRM Implications, Mediating Effect of Management Capability: An Implementation on Islamic Banking," Procedia - Social and Behavioral Sciences, vol. 235, pp. 807-816, 2016. https://doi.org/10.1016/j.sbspro.2016.11.089.

[6] L. Hui and G. Qin-xuan, "Procedia Earth and Planetary Science Performance appraisal : what's the matter with you ?," PROEPS, vol. 1, pp. 1751-1756, 2009. https://doi.org/10.1016/j.proeps.2009.09.268.

[7] R. A. Sari, R. Yuniarti, and F. R. N. Safitri, "Evaluasi Kinerja Perusahaan Berdasarkan Perspektif Organisasi, Proses, dan Staf Berbasis AHP dan OMAX," Jurnal Teknik Industri, vol. 19, pp. 52-60, 2018. https://doi.org/10.22219/jtiumm.vol19.no1.52-60.

[8] C. Kurniawan, A. Mubin, and H. M. Kholik, "Perancangan Integrated Environmental Performance Measurement System Di Rumah Sakit," Jurnal Teknik Industri, vol. 18, p. 9, 2017. https://doi.org/10.22219/jtiumm.vol18.no1.9-18.

[9] O. Olubiyi, G. Smiley, H. Luckel, and R. Melaragno, "A qualitative case study of employee turnover in retail business," Heliyon, vol. 5, p. e01796, 2019. https://doi.org/10.1016/j.heliyon.2019.e01796.

[10] R. de Reuver, K. Van de Voorde, and S. Kilroy, "When do bundles of high performance work systems reduce employee absenteeism? The moderating role of workload," International Journal of Human Resource Management, vol. 0, pp. 1-21, 2019. https://doi.org/10.1080/09585192.2019.1616594.

[11] S. Park, "Motivating raters through work design: Applying the job characteristics model to the performance appraisal context," Cogent Psychology, vol. 4, pp. 1-13, 2017. https://doi.org/10.1080/23311908.2017.1287320.

[12] Z. Ibrahim, A. Ismail, N. A. K. Mohamed, and N. S. M. Raduan, "Association of Managers' Political Interests towards Employees' Feelings of Distributive Justice and Job Satisfaction in Performance Appraisal System," Procedia - Social and Behavioral Sciences, vol. 224, pp. 523-530, 2016. https://doi.org/10.1016/j.sbspro.2016.05.429. 
[13] X. Islami, E. Mulolli, and N. Mustafa, "Using Management by Objectives as a performance appraisal tool for employee satisfaction," Future Business Journal, vol. 4, pp. 94-108, 2018. https://doi.org/10.1016/j.fbj.2018.01.001.

[14] E. Arnăutu and I. Panc, "Evaluation Criteria for Performance Appraisal of Faculty Members," Procedia - Social and Behavioral Sciences, vol. 203, pp. 386-392, 2015. https://doi.org/10.1016/j.sbspro.2015.08.313.

[15] M. Rokhim, "Penentuan Key Performance Indicator Dengan Metode Balanced $\begin{array}{lllll}\text { Scorecard," } & \text { vol. } & 18, & \text { pp. }\end{array}$ https://doi.org/10.22219/JTIUMM.Vol18.No2.168-175.

[16] G. Rusu, S. Avasilcăi, and C.-A. Huțu, "Organizational Context Factors Influencing Employee Performance Appraisal: A Research Framework," Procedia - Social and Behavioral Sciences, vol. 221, pp. 57-65, 2016. https://doi.org/10.1016/j.sbspro.2016.05.090.

[17] R. S. Ilhami and D. Rimantho, "Penilaian Kinerja Karyawan dengan Metode AHP dan Rating Scale," Jurnal Optimasi Sistem Industri, vol. 16, p. 150, 2017. https://doi.org/10.25077/josi.v16.n2.p150-157.2017.

[18] R. Devi, N. Arin, R. Astuti, and D. M. Ikasari, "Penilaian Kinerja Pemasok Susu Segar Menggunakan Metode Analytic Network Process Dan Rating Scale : Studi Kasus Di Pusat Koperasi Industri Susu Sekar Tanjung Pasuruan Performance Appraisal Of Fresh Milk Supplier Using Analytic Network Process Method And R," vol. 14, pp. 131-140, 2013. www.jtp.ub.ac.id/index.php/jtp/article/view/402.

[19] E. Sestri, "Penilaian Kinerja Dosen Dengan Menggunakan Metode AHP Studi Kasus Di Stie Ahmad Dahlan Jakarta," Jurnal Liquidity, vol. 2, pp. 100-109, 2013. www.ojs.itb-ad.ac.id/index.php/LQ/article/view/136.

[20] Saefudin and W. Sri, "Sistem Penunjang Keputusan Penilaian Kinerja Pegawai Menggunakan Metode Analytical Hierarchy Process (Ahp)," Jurnal Sistem Informasi, vol. 1, pp. 33-37, 2014. https://doi.org/10.36723/juri.v9i2.107.

[21] Subiyanto, Hermanto, U. M. Arief, and A. Y. Nafi, "An accurate assessment tool based on intelligent technique for suitability of soybean cropland: case study in Kebumen Regency, Indonesia," Heliyon, vol. 4, 2018. https://doi.org/10.1016/j.heliyon.2018.e00684.

[22] G. Campeol, S. Carollo, and N. Masotto, "Infrastructural Projects and Territorial Development in Veneto Dolomites: Evaluation of Performances through AHP," Procedia - Social and Behavioral Sciences, vol. 223, pp. 468-474, 2016. https://doi.org/10.1016/j.sbspro.2016.05.294.

[23] W. Labib Ashraf and J. Shah, "Management decisions for a continuous improvement process in industry using the analytical hierarchy process," Work Study, vol. 50, pp. 189-194, 2001. https://doi.org/10.1108/EUM0000000005678.

[24] H. H. Azwir and E. B. Pasaribu, "Pemilihan Supplier Menggunakan Metode Analytic Network Process Di PT UTPE," Jurnal Teknik Industri, Vol. 18, No.02, Agustus 2017, pp. 103-112, vol. 18, pp. 103-112, 2017. https://doi.org/10.22219/JTIUMM.Vol18.No2.103-112.

[25] M. L. Tseng, J. H. Chiang, and L. W. Lan, "Selection of optimal supplier in supply chain management strategy with analytic network process and choquet integral," Computers and Industrial Engineering, vol. 57, pp. 330-340, 2009. https://doi.org/10.1016/j.cie.2008.12.001.

[26] R. Whitaker, "Validation examples of the Analytic Hierarchy Process and Analytic Network Process," Mathematical and Computer Modelling, vol. 46, pp. 840-859, 2007. https://doi.org/10.1016/j.mcm.2007.03.018. 
[27] T. Sylvia, A. Hidayat, and S. A. Putri, "Berdasarkan Kompetensi Dengan Menggunakan Metode Analytic Network Process ( Anp ) Dan Rating Scale ( Studi Kasus Di Pg . Pesantren Baru , Kediri )", Jurnal Manajemen, vol. 2, pp. 131-142, 2013.

[28] S. Sonnentag, "Recovery, Work Engagement, and Proactive Behavior: A New Look at the Interface Between Nonwork and Work," Journal of applied psychology, vol. 88, pp. 518-528, 2003. https://doi.org/10.1037/0021-9010.88.3.518.

[29] M. Ayu Mardyaning, A. Retno, and P. Shyntia Atica, "Penilaian Kinerja Kepala Bagian Produksi Dengan Metode Anp Dan Rating Scale ( Studi Kasus Di PT. Performance Appraisal of Production Head Using Anp Method and Rating Scale ( Case Study in PT," Jurnal Industria, vol. 2, pp. 47-56, 2012. www.industria.ub.ac.id/index.php/industri/article/view/127.

[30] T. L. Saaty, "Decision making - the Analytic Hierarchy and Network Processes (AHP/ANP)," Journal of Systems Science and Systems Engineering, vol. 13, pp. 135, 2004. https://doi.org/10.1007/s11518-006-0151-5.

[31] B. Waryanto and Y. A. Millafati, "Transformasi data skala ordinal ke interval dengan menggunakan makro Minitab," Informatika Pertanian, vol. 15, pp. 881895, 2006. www.litbang.pertanian.go.id/warta-ip/pdf-file/4.budiwaryantoipvol15.pdf.

[32] A. C. Lakoy, "Pengaruh komunikasi, kerjasama kelompok, dan kreativitas terhadap kinerja karyawan pada hotel aryaduta Manado," Jurnal EMBA: Jurnal Riset Ekonomi, Manajemen, Bisnis dan Akuntansi, vol. 3, 2015. www.ejournal.unsrat.ac.id/index.php/emba/article/view/9773.

[33] Samsuni, "Manajemen Sumber Daya Manusia," Al Falah, vol. XVII, pp. 113-124, 2017.

[34] M. Marpaung, "Pengaruh Lingkungan Kerja Dan Tingkat Penghasilan Terhadap Peningkatan Poduktivitas Karyawan Pada Rokok Sinar Tunggal Jaya Malang, UIN PRESS," Kepemimpinan, Kerja Kelompok, Kinerja, vol. 2, pp. 33-40, 2013.

[35] M. Ali, S. Lei, and X.-Y. Wei, "The mediating role of the employee relations climate in the relationship between strategic HRM and organizational performance in Chinese banks," Journal of Innovation \& Knowledge, vol. 3, pp. 115-122, 2018. https://doi.org/10.1016/j.jik.2016.12.003.

[36] A. P. Widyassari, "Aplikasi Sistem Pendukung Keputusan Penilaian Kinerja Karyawan untuk Kenaikan Gaji pada PT AAA," Intensif, vol. 1, pp. 92-101, 2017. https://doi.org/10.29407/intensif.v1i2.836.

[37] J. Atiqoh, I. Wahyuni, and D. Lestantyo, "Faktor-Faktor yang Berhubungan dengan Kelelahan Kerja pada Pekerja Konveksi Bagian Penjahitan di CV. Aneka Garment Gunungpati Semarang," Jurnal Kesehatan Masyarakat Universitas $\begin{array}{lllll}\text { Diponegoro, } & \text { vol. } & 2, & \text { pp. } & 119-126,\end{array}$ www.ejournal3.undip.ac.id/index.php/jkm/article/view/6386.

[38] C. Melina Taurisa and R. Intan, "Analisis pengaruh budaya organisasi dan kepuasan kerja terhadap komitmen organisasional dalam meningkatkan kinerja karyawan (Studi pada PT. Sido Muncul Kaligawe Semarang)," Jurnal Bisnis dan ekonomi, $\quad$ vol. 19 2012. www.unisbank.ac.id/ojs/index.php/fe3/article/download/1740/650. 